\title{
Isolation and characterization of Bacillus coagulans associated with half-moon disorder of honey bees
}

\author{
JD Vandenberg *, **, H Shimanuki \\ USDA-ARS Beneficial Insects Laboratory, Beltsville, MD, 20705, USA
}

(Received 13 September 1989; accepted 14 March 1990)

\begin{abstract}
Summary - Nine different isolates of the bacterium Bacillus coagulans were isolated from honey bee larval cadavers collected from colonies afflicted with hall-moon disorder (HMD) in New Zealand. One isolate was selected for detailed characterization and pathogenicity testing. Laboratory-reared larvae became infected when inoculated with the test isolate at 1 or $2 \mathrm{~d}$ of age. No infection was observed among larvae inoculated in combs placed in small colonies in outdoor cages. Although able to infect larvae under certain conditions, $B$ coagulans is probably not the cause of HMD.
\end{abstract}

\section{Bacillus coagulans / Apis mellifera / honey bee larvae / half-moon disorder}

\section{INTRODUCTION}

Half-moon disorder (HMD) was first described from diseased larvae of the honey bee, Apis mellifera, in New Zealand (Anon, 1982). The name is derived from the appearance of afflicted larvae (1-4 d-old) that die while curled in a "half-moon" position at the bottom of their cells. The etiology and epizootiology of the disease are unknown. The distribution of the disease is apparently restricted to New Zealand; concern in North America is based on the possible importation of diseased adult bees.

The isolation, identification and determination of pathogenicity of micro-organisms associated with dead larvae obtained from colonies with HMD were the objectives of this study. We report results of the following experiments :

- isolation and identification of a bacterium from cadavers from colonies with HMD;

- laboratory tests of pathogenicity of the bacterium;

- and infectivity tests in small hives in outdoor flight cages.

A preliminary report of some of our studies has been presented previously (Vandenberg and Shimanuki, 1985).

\footnotetext{
- Correspondence and reprints.

** Present address : USDA ARS Utah State University, Bee Biology \& Systematics Laboratory, Logan, UT, 84322-5310, USA
} 


\section{MATERIALS AND METHODS}

\section{Isolation}

Cadavers were collected from diseased colonies in New Zealand between 1983-1985. Upon arrival at our laboratory they were stored at $4^{\circ} \mathrm{C}$ for $0-4$ months. Each of the 20 individual cadavers was suspended in $1 \mathrm{ml}$ of sterile distilled water and ground in a tissue homogenizer. Suspensions were examined by light microscopy. Replicate tubes of nutrient broth (DIFCO) and glucose-phosphate broth (Bailey and Collins, 1982) were inoculated with other portions of the suspensions. The tubes were incubated at $34{ }^{\circ} \mathrm{C}$ under aerobic or anaerobic conditions. Transfers of visible growth were made to fresh agar-based media for isolation after 1-2 d.

\section{Characterization}

One isolate, identical to others of the most common isolate based on colony morphology and light microscope observations, was chosen for more complete characterization and infectivity testing. It was identified according to the procedures of Gordon et al (1973) with the following exceptions. Stained cells were measured at $1600 \times$ magnification using light microscopy. Cultures for the motility test were grown in nutrient broth. Tests for minimum and maximum temperatures of growth were conducted with cultures grown in nutrient broth. Growth at 10 ${ }^{\circ} \mathrm{C}$ was assessed at $21 \mathrm{~d}$, at $20^{\circ} \mathrm{C}$ at $14 \mathrm{~d}$, and at 50,55 and $60^{\circ} \mathrm{C}$ at $5 \mathrm{~d}$. Anaerobic growth was assessed using Difco thioglycollate medium without indicator. Egg yolk reaction was tested using nutrient broth plus $1 \% \mathrm{NaCl}$ to which a $15 \%$ egg yolk suspension was added. The lysozyme test was not conducted.

Eight additional isolates were subjected to 8 tests necessary to identify the species according to the key provided by Gordon et al (1973). The tests used were : gram reaction, spore location within the sporangium, spore swelling of the sporangium, growth at $50^{\circ} \mathrm{C}$, catalase production, anaerobic growth, Voges-Proskauer (VP) test for the production of acetyimethlycarbinol, $\mathrm{pH}$ in VP broth, and growth in $7 \% \mathrm{NaCl}$.

\section{Laboratory Pathogenicity Tests}

Honey bee larvae were reared in the laboratory according to the procedure of Vandenberg and Shimanuki (1987). Inocula were prepared by growing the bacterium on nutrient agar plates for 4-7 d, scraping the growth off with a sterile glass cover slip, and suspending bacteria in sterile potassium phosphate buffer $\left(0.1 \mathrm{~mol} \cdot \mathrm{l}^{-1}\right.$, pH 6.8). The concentration of viable bacteria in colony-forming units (CFU) was determined by plating a series of dilutions of the inoculum on nutrient agar and counting the colonies after $48 \mathrm{~h}$. The inoculum $(1 \mu)$ was added to the food of 1,2 or 3-d-old larvae using a Hamilton repeating syringe. The food of control larvae was inoculated with buffer only. Larvae were observed twice daily for any signs of infection and for survival to the prepupal stage.

The adult weights of larvae that survived inoculation as 1-d-old larvae were compared with buffer-inoculated controls. Each adult was weighed to the nearest $\mathrm{mg}$. Significance of differences between treated and control bees for each test was determined by comparing overlapping means \pm standard deviation.

\section{Microscopy}

Digestive tracts of inoculated and control larvae from laboratory tests were removed by dissection and fixed for 2-4 $\mathrm{d}$ in caccodylate-buffered $\left(0.2 \mathrm{~mol}^{-1}, \mathrm{pH} 7.2\right)$ glutaraldehyde $(1.5 \%)$ at $4^{\circ}$. They were post-fixed in $2 \%$ aqueous osmium tetroxide for $1 \mathrm{~h}$ and rinsed in distilled water. Tissue dehydration was accomplished with a graded ethanol series. Specimens were dried using liquid $\mathrm{CO}_{2}$ in a critical point dryer, mounted on double-stick tape and coated under vacuum with a gold-palladium alloy. They were examined at 10-20 kV using a Jeol T-300 scanning electron microscope for signs of bacterial multiplication.

\section{Pathogenicity Tests in Hives}

Nucleus colonies were established in outdoor flight cages (dimensions $2 \times 2 \times 2 \mathrm{~m}$ ). Each colony consisted of a queen, ca 5000 adult worker 
bees, 2 frames with brood and 2 frames with nectar and pollen stores. Colonies were provided with sucrose syrup (50\% wt/wt), pollen substitute (Beltsville Bee Diet, BioServe Inc) and water ad libitum. Larvae of known age were obtained trom free-flying colonies by confining the queen to a small section of comb for 4-8 h. Frames with resulting larvae of known age were removed, inoculated, placed in the caged colonies, and observed daily for their presence and survival. Two replicate tests each were conducted with 10-, 20-, and 44- h-old larvae. One test was performed using 56 and 96-h-old larvae. Ten- and 20-h-old larvae were inoculated with $8.5 \times 10^{6} \mathrm{CFU} / \mathrm{larva}$. Older larvae were inoculated with $1 \times 10^{6} \mathrm{CFU} /$ larva. The percentage of larvae remaining for each treatment after $7 \mathrm{~d}$ was subjected to angular transformation before analysis of variance.

Isolates from living and dead larvae were obtained at regular intervals throughout the laboratory and hive inoculation tests. They were maintained on nutrient agar and compared to initial isolates using the 8 tests described above.

\section{RESULTS}

\section{Isolation}

Eighteen of the 20 homogenized cadavers contained a sporulating gram-positive rodshaped bacterium. Colonies grew readily and spread when transferred to both nutrient agar and glucose-phosphate agar. The isolates grew under both aerobic and anaerobic conditions. We also isolated a gram-positive aerobic streptococcal bacterium from 2 cadavers on both media. We did not characterize these isolates further. Bacteria associated with European (Melissococcus pluton, Bacillus alvei) and American foulbrood (Bacillus larvae) were not observed or isolated. Our failure to isolate other bacteria may have been due to the rapid growth of the rod-shaped bacillus in broth cultures. No fungi were observed in smears, nor were any isolated. We did not test for the presence of viruses or other micro-organisms.

\section{Characterization}

The isolate chosen for extensive characterization had average cell dimensions of 3.8 $x 0.6 \mu \mathrm{m}(N=100)$. The spores were ellipsoidal in shape, located paracentrally to subterminally within the sporangium, and caused the sporangium to swell. The following tests yielded positive results: gram reaction; motility; catalase production; anaerobic growth; VP test; growth at $\mathrm{pH}$ 5.7; growth in $0.02 \%$ azide; growth in $5 \% \mathrm{NaCl}$; acid production from glucose, arabinose, xylose and mannitol; starch hydrolysis, citrate utilization, and dihydroxyacetone formation. Negative results were as follows: no growth in $7 \%$ or $10 \% \mathrm{NaCl}$, no gas from glucose or other carbohydrates, no propionate utilization, no reduction of $\mathrm{NO}_{3}$ to $\mathrm{NO}_{2}$, no indole formation, no casein or tyrosine decomposition, no deamination of phenylalanine, and no utilization of egg yolk. The litmus-milk reaction resulted in weak acid $\mathrm{pH}$, reduction of the substrate, and production of a ropy curd. The minimum growth temperature was $20^{\circ} \mathrm{C}$ and the maximum was $55^{\circ} \mathrm{C}$. The $\mathrm{pH}$ in VP broth was 4.4.

All 8 additional isolates were positive for growth at $50{ }^{\circ} \mathrm{C}$, catalase production, anaerobic growth, and the VP test. The $\mathrm{pH}$ in VP broth ranged from 4.4 to 5.2. Six of the 8 strains were able to grow in $7 \% \mathrm{NaCl}$. All strains were gram-positive, the spores swelled the sporangium, and were paracentrally to subterminally located.

The results obtained from various tests of 9 isolates allow us to identify this organism as Bacillus coagulans when following procedures established by Gordon et al (1973). 


\section{Laboratory Pathogenicity Tests}

The results of infectivity tests conducted using laboratory-reared larvae are shown in table I. Although we tested several doses, the tests were neither designed nor analyzed as a proper statistical bioassay. Some conclusions are possible, however. One-d-old larvae were the most susceptible to infection by $B$ coagulans, especially at doses higher than ca $2 \times 10^{6} \mathrm{CFU} / \mathrm{larva}$ (table I). However, some disease occurred at the lowest dose $\left(6 \%\right.$ at $7 \times 10^{3} \mathrm{CFU} /$ larva). Sixty-two percent mortality of larvae inoculated at $1 d$ of age was obtained at doses of $2.5 \times 10^{6}$ and $3.5 \times 10^{6} \mathrm{CFU} /$ larva; $48 \%$ mortality occurred at a dose of $1 \times 10^{7} \mathrm{CFU} / \mathrm{larva}$. Larvae inoculated at $2 d$ of age appeared to be much less susceptible since disease incidence was usually $0 \%$ and was not higher than $3 \%$ at any dosage tested. Three-d-old larvae receiving $3.5 \times 10^{6} \mathrm{CFU}$ each did not express any signs of disease, and none of the buffer-inoculated larvae became diseased.

Twenty-six adults inoculated as larvae with $1.2 \times 10^{6} \mathrm{CFU} /$ larva had an average weight of $111 \pm 15 \mathrm{mg}$. Twenty-three controls had an average weight of $108 \pm$ $17 \mathrm{mg}$. For 6 adults surviving inoculation with $2.5 \times 10^{6} \mathrm{CFU} / \mathrm{larva}$, the average weight was $97 \pm 14 \mathrm{mg}$. Nineteen control adults had an average weight of $100 \pm 21$ $\mathrm{mg}$. The average weight of 28 adults surviving inoculation with $1 \times 10^{7} \mathrm{CFU} / \mathrm{larva}$ was $125 \pm 16 \mathrm{mg}$. Thirty-seven controls had an average weight of $112 \pm 16 \mathrm{mg}$. For each of the 3 tests, there was significant overlap of the ranges. Therefore, we found no significant differences between the adult weights of surviving treated and control bees.

\section{Microscopy}

Within $1 \mathrm{~d}$ of inoculation, bacteria were observed multiplying within larval guts (fig 1). Most of the diseased larvae died at $1-4 \mathrm{~d}$ after inoculation. There was no apparent relationship between dose and time to death. We did not determine bacterial multiplication rates within inoculated larvae. $B$ coagulans was readily re-isolated from bacteria-inoculated larvae (diseased or healthy) and from their feces. The bacterium was not isolated from uninoculated control larvae. Diseased larvae often became discolored after death, forming brown scales curled within their cells (fig $2 a)$, and they were filled with spores and vegetative cells of this bacterium.

\section{Pathogenicity Tests in Hives}

Inoculation of larvae in their original comb cells failed to produce disease. Dead or diseased larvae were not found following any of the treatments, nor was there any sign of disease within the colonies for 3 months following the treatments. (The colonies were then destroyed). B coagulans was readily re-isolated from bacteriainoculated larvae and from empty cells after adult bees had removed the treated larvae.

The proportion of larvae remaining in their cells $1 \mathrm{wk}$ after treatment was lowest in all cases for the bacteria-inoculated treatment (table Ii). However, there were no significant differences in the number of remaining larvae between those inoculated with bacteria and those inoculated with buffer. Thus, the disturbance involved in inoculation may have led to the removal of larvae by the adults. In the tests of 10-h- 
Table 1. Percent healthy prepupae and percent disease among laboratory reared honey bee larvae inoculated with different doses of Bacillus coagulans. a Dose in colony-forming-units per larva. ${ }^{b}$ Age of larvae, in d, at inoculation.

\begin{tabular}{|c|c|c|c|c|}
\hline Dose a & $A g e^{b}$ & No inoculated & PCT prepupae & PCT disease \\
\hline $7 \times 10^{3}$ & $\begin{array}{l}1 \\
2\end{array}$ & $\begin{array}{l}66 \\
36\end{array}$ & $\begin{array}{l}88 \\
89\end{array}$ & $\begin{array}{l}6 \\
0\end{array}$ \\
\hline Buffer & $\begin{array}{l}1 \\
2\end{array}$ & $\begin{array}{l}66 \\
35\end{array}$ & $\begin{array}{l}91 \\
91\end{array}$ & $\begin{array}{l}0 \\
0\end{array}$ \\
\hline $2 \times 10^{4}$ & $\begin{array}{l}1 \\
2\end{array}$ & $\begin{array}{l}28 \\
30\end{array}$ & $\begin{array}{l}96 \\
93\end{array}$ & $\begin{array}{l}4 \\
3\end{array}$ \\
\hline Buffer & $\begin{array}{l}1 \\
2\end{array}$ & $\begin{array}{l}32 \\
33\end{array}$ & $\begin{array}{l}97 \\
97\end{array}$ & $\begin{array}{l}0 \\
0\end{array}$ \\
\hline $6 \times 10^{5}$ & $\begin{array}{l}1 \\
2\end{array}$ & $\begin{array}{l}72 \\
24\end{array}$ & $\begin{array}{l}89 \\
96\end{array}$ & $\begin{array}{l}0 \\
0\end{array}$ \\
\hline Buffer & $\begin{array}{l}1 \\
2\end{array}$ & $\begin{array}{l}67 \\
23\end{array}$ & $\begin{array}{l}78 \\
87\end{array}$ & $\begin{array}{l}0 \\
0\end{array}$ \\
\hline $1.2 \times 10^{6}$ & $\begin{array}{l}1 \\
2\end{array}$ & $\begin{array}{l}43 \\
45\end{array}$ & $\begin{array}{l}60 \\
87\end{array}$ & $\begin{array}{l}9 \\
2\end{array}$ \\
\hline Buffer & $\begin{array}{l}1 \\
2\end{array}$ & $\begin{array}{l}45 \\
48\end{array}$ & $\begin{array}{r}67 \\
100\end{array}$ & $\begin{array}{l}0 \\
0\end{array}$ \\
\hline $2.5 \times 10^{6}$ & $\begin{array}{l}1 \\
2\end{array}$ & $\begin{array}{l}21 \\
34\end{array}$ & $\begin{array}{l}29 \\
88\end{array}$ & $\begin{array}{r}62 \\
3\end{array}$ \\
\hline Buffer & $\begin{array}{l}1 \\
2\end{array}$ & $\begin{array}{l}24 \\
23\end{array}$ & $\begin{array}{l}75 \\
83\end{array}$ & $\begin{array}{l}0 \\
0\end{array}$ \\
\hline $3.5 \times 10^{6}$ & $\begin{array}{l}1 \\
3\end{array}$ & $\begin{array}{l}16 \\
24\end{array}$ & $\begin{array}{l}25 \\
92\end{array}$ & $\begin{array}{r}62 \\
0\end{array}$ \\
\hline Buffer & $\begin{array}{l}1 \\
3\end{array}$ & $\begin{array}{l}24 \\
24\end{array}$ & $\begin{array}{r}96 \\
100\end{array}$ & $\begin{array}{l}0 \\
0\end{array}$ \\
\hline $1 \times 10^{7}$ & 1 & 64 & 48 & 48 \\
\hline Buffer & 1 & 57 & 72 & 0 \\
\hline
\end{tabular}

old larvae, there were significantly more untreated larvae than treated larvae remaining 1 wk after inoculation (table II; analysis of variance: $F=12.6 ; d f=2,3$;
$P=0.03$ ). In the tests of 20 -h-old and $44-$ $h$-old larvae there were no differences among the 3 treatment groups (table II; 20h; $F=2.9 ; d f=2,3 ; P=0.2 ; 44-h: F=0.2$; 

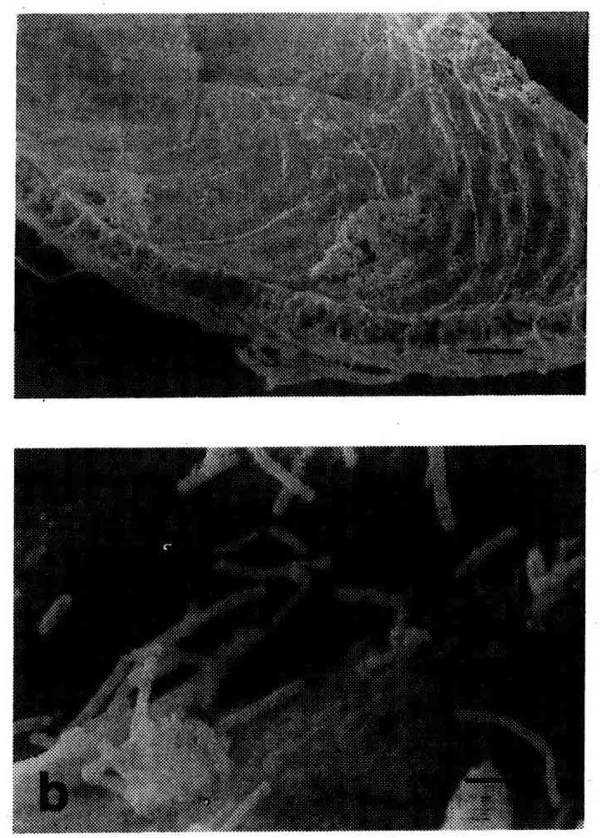

Fig 1. Bacillus coagulans within the midgut lumen of a larva $1 \mathrm{~d}$ after inoculation.

$d f=2,3 ; P=0.83$ ). It is possible that some larvae inoculated with bacteria in colonies became diseased and were removed from their cells before we were able to observe them. We feel this is unlikely, however, because we observed the larvae daily and many buffer-inoculated control larvae were also removed.

The tests of 56-h-old and 96-h-old larvae resulted in the removal of all larvae by adult bees within $3 \mathrm{~d}$ after inoculation $(N=$ 262 and $N=207$, respectively). These results, and the rather low numbers of remaining 44-h-old larvae (table II), may have been due to the stressed condition of the caged colonies. At the time of these tests, the colonies had been caged for almost 2 months.
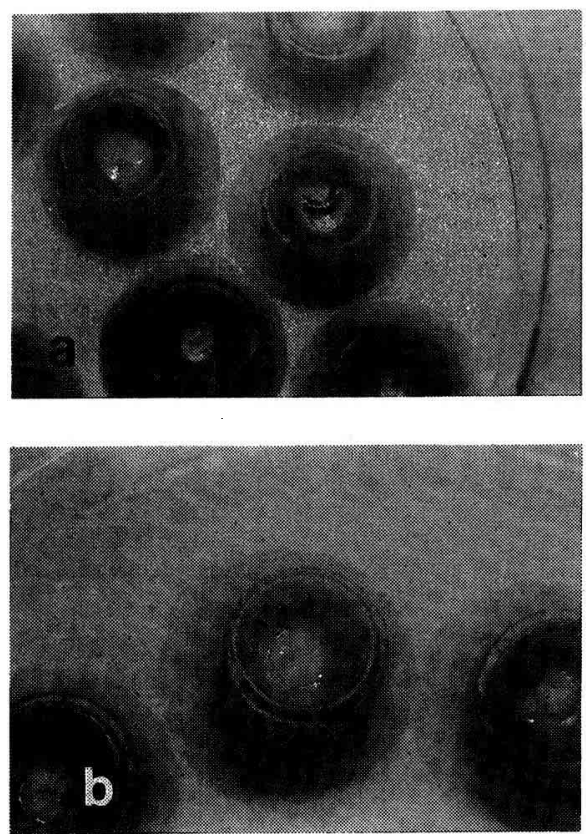

Fig 2. Laboratory-reared diseased (a) and healthy (b) larvae $3 \mathrm{~d}$ after inoculation with Bacillus coagulans.

\section{DISCUSSION}

Although $B$ coagulans has been isolated previously from adult bees, this is the first report of the isolation of this bacterium from honey bee larvae. El-Leithy and ElSibaei (1972) isolated $B$ coagulans, among other bacilli, from adult workers. Gilliam and Valentine (1976) and Gilliam (1978) isolated $B$ coagulans from the digestive tracts of an adult worker and an adult queen, respectively.

$B$ coagulans is probably not the cause of HMD. HMD appears to be a disorder associated with queens ( $D$ Anderson, DSIR, Entomology Division, Auckland, New Zealand, unpublished report). Attempts to spread HMD by transferring combs with 
Table II. Honey bee larvae remaining in the hive in their original comb cells following inoculation with Bacillus coagulans. a Age of larvae, in hours, at inoculation. b Dose for $10 \mathrm{~h}$ and $20 \mathrm{~h}=8.5 \times 10^{6}$, dose for $44 \mathrm{~h}=1 \times 10^{6}$. c Total of two replicates for each age-treatment combination. $d$ Percent remaining in their original cells after $7 \mathrm{~d}$. Means within each age group followed by the same letter are not significantly different by analysis of variance (Student-Newman-Keuls test, $P<0.05$ ).

\begin{tabular}{llcc}
\hline Age a & Treatment $^{b}$ & No inoculated $^{c}$ & PCT remaining $^{d}$ \\
\hline 10 & Untreated & 77 & $97 \mathrm{a}$ \\
& Buffer & 81 & $65 \mathrm{~b}$ \\
& $B$ coagulans & 74 & $54 \mathrm{~b}$ \\
20 & Untreated & 53 & $92 \mathrm{a}$ \\
& Buffer & 54 & $87 \mathrm{a}$ \\
& B coagulans & 56 & $71 \mathrm{a}$ \\
44 & Untreated & 37 & $58 \mathrm{a}$ \\
& Buffer & 40 & $50 \mathrm{a}$ \\
& B coagulans & 46 & $39 \mathrm{a}$ \\
\hline
\end{tabular}

dead worker larvae to healthy colonies have failed. Transferring queens from afflicted colonies to previously healthy ones resulted in the onset of HMD (Anderson, unpublished). However, given the relatively high frequency with which we isolated $B$ coagulans from half-moon cadavers (18 out of 20), this bacterium may contribute to the expression of the disorder. For example, its presence in larval cells may increase the chances for a larva to be neglected by adult nurse bees.

While we have not been able to produce the signs of HMD in our tests, we have shown that, under certain conditions, $B$ coagulans can be pathogenic for honey bee larvae. We were able to infect laboratoryreared larvae inoculated at 1 or $2 \mathrm{~d}$ of age. We were not able to cause disease in 3-dold larvae, nor were we able to infect larvae in small colonies caged outdoors.

\section{ACKNOWLEDGMENTS}

Valuable technical assistance was provided by A Lemansky. Helpful comments were provided for a draft of this manuscript by MC Rombach and PF Torchio. Partial support during the analysis and manuscript preparation phases of this work was provided by the Utah Agricultural Experiment Station, Journal Paper No 3906.

Résumé - Isolement et caractérisation de Bacillus coagulans associé à l'affection en demi-lune des abeilles. Des cadavres de larves d'abeilles ont été récoltés en Nouvelle-Zélande dans des colonies touchées par l'affection en demi-lune (HMD). L'HMD semble restreinte à la Nouvelle-Zélande, où elle a été décrite pour la première fois (Anon, 1982) et l'Amérique du Nord s'inquiète d'une éventuelle importation d'abeilles adultes malades. Bacillus coagulans a été identifié dans 18 des 20 cadavres examinés et 9 isolats ont été caractérisés. Le pouvoir pathogène de l'un des isolats vis-à-vis de l'abeille a été testé. Les larves élevées en laboratoire ont été plus sensibles à l'infection lorsque la bactérie leur avait été inoculée à l'âge d'un jour et lorsque la dose d'inoculation était supérieure à $2 \cdot 10^{6}$ unités formant colonie par larve (tableau I). Les larves âgées de 2 
j ont été bien moins sensibles et celles de 3 j n'ont pas du tout été infectées. La bactérie a été facilement réisolée à partir des larves inoculées, aussi bien malades que saines. Elle s'est multipliée rapidement dans le lumen de l'intestin moyen (fig 1). Les larves malades sont mortes dans les 4 j suivant l'inoculation et certaines d'entre elles ont donné un cadavre brun foncé (fig 2). II n'y a pas eu de différence pondérale entre les adultes provenant des larves élevées en laboratoire, qu'elles aient été traitées ou témoins. Aucune infection n'a été décelée parmi les larves d'âge varié ayant été inoculées dans les rayons au sein de petites colonies placées à l'extérieur sous cage. II n'y a pas eu de différence significative entre le nombre de larves restant dans les rayons, qu'elles aient été traitées ou non (tableau II). En conclusion, bien que $B$ coagulans soit capable d'infecter les larves d'ouvrières dans certaines conditions, il est improbable qu'il soit la cause de l'HMD.

\section{Apis mellifica / larve / bactériose / Ba- cillus coagulans}

\section{Zusammenfassung - Isolierung und} Charakterisierung von Bacillus coagulans, gefunden bei der HalbmondKrankheit der Honigbiene. Die Halbmond-Krankheit (HMD) wurde erst vor wenigen Jahren in Bienenvölkern Neuseelands erstmals gefunden. Befallen sind ein- bis viertägige Larven, die sich vor ihrem Tod am Boden der Zelle halbmondartig einrollen. Außerhalb Neuseelands wurde diese Krankheit bisher noch nicht festgestellt. Ziel dieser Untersuchung ist die Isolierung und Bestimmung des Erregers. Tote Larven der Honigbiene wurden aus Völkern in Neuseeland, die an der Halbmond-Krankheit litten, gesammelt. Aus 18 von 20 untersuchten Larven wurde Bacillus coagulans isoliert. Neun Isolate wurden mit Spezialmethoden weiter untersucht. Ein Isolat wurde auf seine krankheitsauslösende Wirkung auf Bienenlarven untersucht. Im Labor aufgezogene Larven waren für die Infektion bei Impfung am ersten Lebenstag mit einer Dosis von über $2 \times 10^{8}$ von koloniebildenden Einheiten pro Larve am empfindlichsten (Tabelle I). Zwei Tage alte Larven waren viel weniger empfindlich und drei Tage alte Larven wurden überhaupt nicht infiziert. Das Bakterium konnte leicht sowohl aus kranken wie gesunden geimpften Larven rückisoliert werden. Das Bakterium vermehrte sich sehr rasch im Inneren des Mitteldarms (Abb 1). Erkrankte Larven starben innerhalb von 14 Tagen nach der Impfung, manche unter Bildung eines dunkelbraunen Kadavers (Abb 2). Es wurde kein Gewichtsunterschied der erwachsenen Bienen von denen im Labor aufgezogenen Larven festgestellt, gleich ob sie behandelt oder nicht behandelt waren. In gekäfigten Freilandvölkern wurde nach Impfung von Larven verschiedenen Alters in den Waben keine Infektion festgestellt. Es bestand kein signifikanter Unterschied zwischen der Zahl der Larven, die in den Waben von geimpften und Kontrollvölkern am Leben blieben (Tabelle II). Als Schlußfolgerung kann festgestellt werden, daß $B$ coagulans höchstwahrscheinlich nicht die Ursache der Halbmondkrankheit ist, obwohl unter bestimmten Bedingungen Arbeiterlarven infiziert werden können.

\section{Bacillus coagulans / Apis mellifera / Larve / Halbmond-Krankheit}

\section{REFERENCES}

Anonymous (1982) Mystery disease leaves them stumped. NZ Beokeoper 44 (4), 4

Bailey L, Collins MD (1982) Taxonomic studies on Streptococcus pluton. J Appl Bacteriol 53, 209-213 
El-Leithy MA, El-Sibaei KB (1972) External and internal microflora of the honey bees (Apis mellifera L). Egypt J Microbiol 7, 79-87

Gilliam M (1978) Bacteria belonging to the genus Bacillus isolated from selected organs of queen honey bees, Apis mellifera. J Invertebr Pathol 31, 389-391

Gilliam M, Valentine DK (1976) Bacteria isolated from the intestinal contents of foraging worker honey bees, Apis mellifera : the genus $\mathrm{Ba}$ cillus. J Invertebr Pathol 28, 275-276
Gordon RE, Haynes WC, Hor-Nay Pang C (1973) The genus Bacillus. USDA Handbook $427,1-283$

Vandenberg JD, Shimanuki H (1985) Isolation and characterization of a Bacillus sp from larvae of the honey bee, Apis mellifera, suffering from half-moon syndrome. In: Proc 18th Ann Mtg Soc Invertebr Pathol. Sault Ste Marie, Ontario, Canada, p 23

Vandenberg JD, Shimanuki H (1987) Technique for rearing worker honeybees in the laboratory. J Apic Res 26, 90-97 